\title{
Dyeing of S/J Cotton Knit Fabric with Natural Dye Extracts from Green Walnut Shells: Assessment of Mordanting Effect on Fastness Properties
}

\author{
Zakaria', Md. Eanamul Haque Nizam², Md. Hasan Al Mamun', Md. Abu Yousuf ${ }^{3}$, Ramjan Ali' ${ }^{3}$, \\ Lutfor Rahman', Md. Raza Miah'
}

${ }^{1}$ School of Chemistry and Chemical Engineering, Wuhan Textile University, Wuhan, China

${ }^{2}$ School of Fashion Design and Engineering, Wuhan Textile University, Wuhan, China

${ }^{3}$ School of Textile Science and Engineering, Wuhan Textile University, Wuhan, China

${ }^{4}$ Department of Textile Engineering, City University, Dhaka, Bangladesh

Email: zakariaonto@gmail.com, razamiah@gmail.com, mham6770@gmail.com, md.eanamulhaque@gmail.com,

Ramjanali43@yahoo.com,yousuf_buft@yahoo.com,Lutbste88@gmail.com

How to cite this paper: Zakaria, Nizam, M.E.H., Al Mamun, M.H., Yousuf, M.A., Ali, R., Rahman, L. and Miah, M.R. (2017) Dyeing of S/J Cotton Knit Fabric with Natural Dye Extracts from Green Walnut Shells: Assessment of Mordanting Effect on Fastness Properties. Journal of Textile Science and Technology, 3, 17-30. https://doi.org/10.4236/jtst.2017.32002

Received: May 6, 2017

Accepted: May 27, 2017

Published: May 30, 2017

Copyright $\odot 2017$ by authors and Scientific Research Publishing Inc. This work is licensed under the Creative Commons Attribution International License (CC BY 4.0).

http://creativecommons.org/licenses/by/4.0/ (c) () Open Access

\begin{abstract}
In this study, aqueous extraction method is used because of its high extraction ratio, light fastness and also functional properties. In $1^{\text {st }}$ phase, for dyeing S/J cotton knit fabric with green walnut power ferrous sulfate is considered as a mordant. In this study, three different mordanting methods such as pre-, meta-, and post-mordanting are conveyed the dyeing process with the state of metallic mordant and without metallic salt mordants. In $2^{\text {nd }}$ phase, in dyeing for fixation ferrous sulfate was considered as mordants. Furthermore, the analysis and evaluation of each colour dyed material was done through following two terms for instance CIELAB ( $\mathrm{L}^{*}, \mathrm{a}^{*}$, and $\mathrm{b}^{*}$ ) and K/S values. According to AATCC test methods, colour fastness to washing, crocking, perspiration of the dyed samples is determined whereas according to the ISO standard, the colour fastness to light was estimated and tested. When dyeing was carried out on $\mathrm{S} / \mathrm{J}$ cotton knit fabric through considering optimum parameter like at $80^{\circ} \mathrm{C}$ for $60 \mathrm{~min}$ and at $\mathrm{pH} 4$ which showed optimum results. From the results we can see, very good wash fastness was obtained while there is no fading of the colour, whereas the outstanding and moderate level of colour fastness to light and crocking is achieved.
\end{abstract}

\section{Keywords}

Green Walnut Shell, Dye, Extraction, S/J Cotton Knit Fabric, Colour Strength, Fastness 


\section{Introduction}

The art of dyeing is as old as our civilization. Dyed textile remnants found during archaeological excavations at different places all over the world provide evidence to the practice of dyeing in ancient civilizations [1]. Natural dyes repeatedly were used only for colouring of textiles from ancient times till the nineteenth century. Natural dyes repeatedly are eco-friendly due to its biodegradability, low toxicity, and UV absorbent than synthetic dyes [2] [3]. Natural dyes have very less demand to the synthetic dyes [4] [5]. But there is a wide scope to use natural dyes. It can be used in food, leather, printing ink, plastics, furniture, from [4] natural fibers (cotton, wool, silk, ramie etc.) [6] [7] [8] [9], synthetic fibers (polyester, nylon, acrylic etc.) [10] and even in dye sanitized solar cells. Different colours can be gotten from fungi, insects, minerals; from animal skins, urine, dunk; different parts of plant like roots, leaves, flowers, barks, fruits, fruit shells [11] [12] [13]. There are a lot of extraction methods for natural dye extraction. Walnut is a popular nut in China seen in Figure 1, USA and Africa [3] [14] [15]. Walnut is very tasty and healthy [16]. The shell of walnut has also been very largely used including pharmaceuticals, cosmetics, non-skid paints, drilling fluids, filtration materials, extenders for adhesive, plastic and rubber materials, carriers for pesticides, herbicides and seeds and for landscape and infill materials [13] [17] [18]. Natural dyes generally require mordant [19]. But it is a big challenge for textile dyer to acceptable properties like colour fastness to wash, light, rubbing etc. [20]. Cellulose fibers are dyed in presence of excessive amount of salt and fixed under alkali [21] [22].

The following objectives are conducted for this research:

- Aqueous extraction of natural dyes from Green walnut shell and identification of colouring compounds.

- Dyeing of S/J cotton knit fabric using different variation of ferrous sulphate mordant to determine the optimum parameter.

- To investigate the colour fastness of Green walnut shell dyed cotton.

- To reduce the process time, energy, cost of material during the extraction process of Green walnut shell.

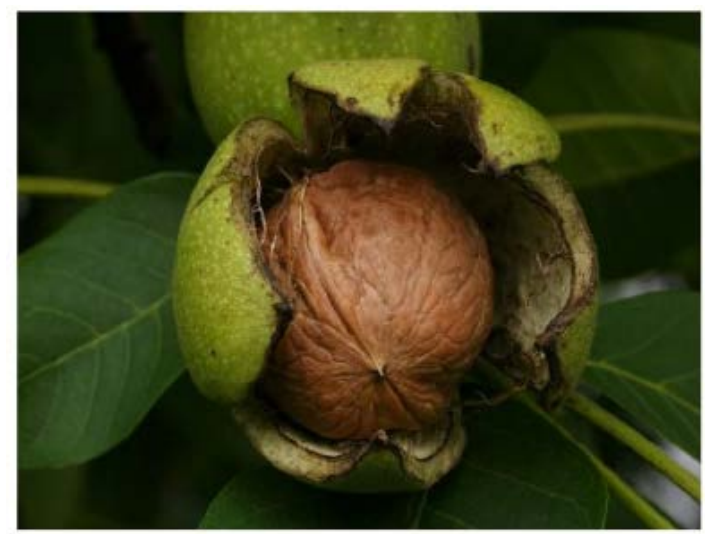

Figure 1. Green walnut shell seed from natural source [3]. 


\section{Principles of research}

Walnut shell makes a bond with water during aqueous extraction process shown in Figure 2.

In Figure 3, also shown when cellulose fabric immersed into water makes co-valent bond with walnut dye.

During pre-, meta- and post-mordanting process, metal mordant makes metal complex bond through ligand formation when walnut dye reacted with S/J cotton knit fabric shown in Figure 4.

\section{Materials and Methods}

\subsection{Materials}

- Green walnut shells were provided from Hubei province, China.

- Seeds of the green walnut shell were used for extraction of dyes.

\subsection{Fabrics}

S/J cotton knit fabric with GSM 120 used for dyeing with the extracted gardenia yellow dyes solution which was bought from Guangdong province.<smiles>O=C1C=CC(=O)c2c(O)cccc21</smiles>

2-Hydroxy-1, 4-naphthoquinone<smiles>O=C1CC(O)C(=O)c2cccc(O)c21</smiles>

5, 8-Dihydroxy-1, 4-naphthoquinone

Figure 2. Chemical reaction of walnut dye (Juglans regia) with water.

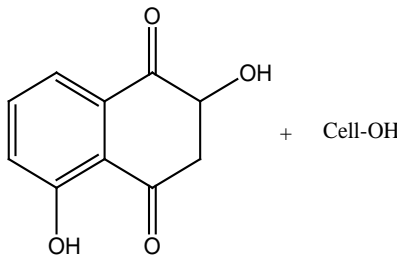

5, 8-Dihydroxy-1, 4-naphthoquinone<smiles>COC1CC(=O)c2c(O)cccc2C1=O</smiles>

Dyed cellulose

Figure 3. Reaction of walnut dye with S/J cotton knit fabric.

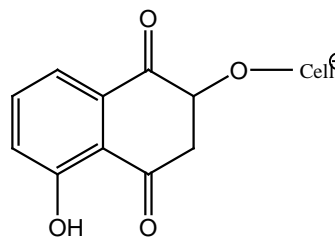

Dyed cellulose

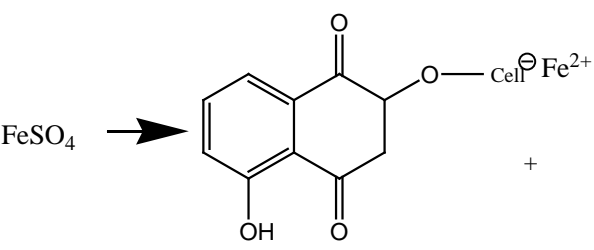

Mordanted cellulose

Figure 4. Reaction of walnut dye with S/J cotton knit fabric by using metal mordant during pre-, meta-and post-mordanting process. 


\subsection{Chemicals}

- Extraction of green walnut shell was carried out by the aqueous mediums which were brought from Xilong Chemical Co. Ltd. in Shantou, Guangdong, China.

- Ferrous sulphate mordant was used which was purchased from the Shandong province, china.

- A non-ionic soaping agent, Metapon X-80, which was supplied from Dymatic Chemicals. Inc. Co. Ltd. (China). Soap and sodium carbonate $\left(\mathrm{Na}_{2} \mathrm{CO}_{3}\right)$ were used to evaluate the colour fastness to washing.

\subsection{Instruments}

For the dye extracting processes were used a Lab spray drier machine (Shanghai Biochemical Ya Rong Instrument Factory, China) and Rotary evaporate machine (Shanghai Bio-Chemical Yarong Instroments Factory). To check the dyes powder form properties were used FTIR. A dyeing machine Rapid (XDS Motor Co,. Ltd, China) was used for the wool fabric dyeing. CIE $L^{\star}, a^{*}, b^{*}, C^{\star}$ and colour strength in terms of K/S values of dyed samples were measured by a USTC spectrophotometer (Datacolour Co., US). All of the coloured samples characteristics were measured under illuminant D65 using the CIE 1964, 10 ${ }^{\circ}$ standard observer and specular component excluded. The light fastness (Q-SUN 1000 Xenon Test Chamber) machine was used to measure the colour changing properties by sun light.

\subsection{Methods}

\subsubsection{Preparation of Green Walnut Shell for Extraction}

The green walnut shells are crushed by the grinder machine for about $2 \mathrm{~min}$. After crushing, 40 grams of gardenia plants are weighted by the digital weighting balance meter.

\subsubsection{Method of Extraction}

During the aqueous extraction process [23] at first dried pieces of green walnut shell were kept at $28^{\circ} \mathrm{C}$ temperature for 24 hours then it was used for dye extraction. The plant materials and distilled water ratio were $1: 3$ and boiled at $100^{\circ} \mathrm{C}$ temperature with $1 \mathrm{~g} / \mathrm{L} \mathrm{NaOH}$ for one and a half hours. At the same time it was stirred when it was boiling. After the getting solution when it was cold then filtered and removed the residue. After that, the final resulting dye solution was separated into two parts: a) half of that solution was used to make the powder form by using a rotary evaporator and spray drier machine, and b) rest of half part aqueous solution were used for the S/J cotton knit fabric dyeing.

\subsubsection{Powder Formation from Green Walnut Shell Dye}

After extraction green walnut shell dyes solution was made into a powder form by using the spray dryer machine. $1000 \mathrm{ml}$ liquid dyes solution was taken in a beaker and spray dryer machines starts to convert the liquid dyes solution into 
powder form. The temperature of the spray dryer machine is about $200^{\circ} \mathrm{C}$ and for making powder form it needs 5 hour. After making powder, it was collected in a separate pot for testing the quality of the gardenia yellow powder dyes.

\subsubsection{Mordanting}

In case of dyeing of natural dyes, different types of mordants are used [24] [25]. Here, Ferrous Sulphate Mordant was used during the dyeing process to find out the best result for cotton knitted dyeing with green walnut shell dyes by following pre-, meta-, post-mordanting method [19]. 40 g/l Aluminium Sulphate solution was made and furthers it was used in together with the dyes solution. When mordant was used together with green walnut shell dyes, it increased the affinity of the dyes to the $\mathrm{S} / \mathrm{J}$ cotton knit fabric. During dyeing process mordants were applied in different amounts in different conical flax with the dyes solution to find out the best dyeing results. Here $1 \mathrm{ml}, 1.5 \mathrm{ml}, 2 \mathrm{ml}, 2.5 \mathrm{ml}, 3 \mathrm{ml}, 3.5 \mathrm{ml}$ mordants were used together with pure gardenia yellow dyes solution in different conical flax. Every conical flax will be marked with different numbering sticker to identify the beakers after the dyeing process.

\section{Results and Discussions}

\subsection{Fourier Transform Infrared Spectroscopy of Green Walnut Shell Dyes}

According to Figure 5, $1150-1300 \mathrm{~cm}^{-1}$ there is a medium wag which indicates that alkyl halide group $\left(-\mathrm{CH}_{2} \mathrm{X}\right)$ is present there. Aromatic amines groups $(\mathrm{C}-\mathrm{N})$ were identified by strong stretch in the wave length $1250-1355 \mathrm{~cm}^{-1}$. Medium stretch in the ring in the wavelength $1400-1500 \mathrm{~cm}^{-1}$ defines the presence of

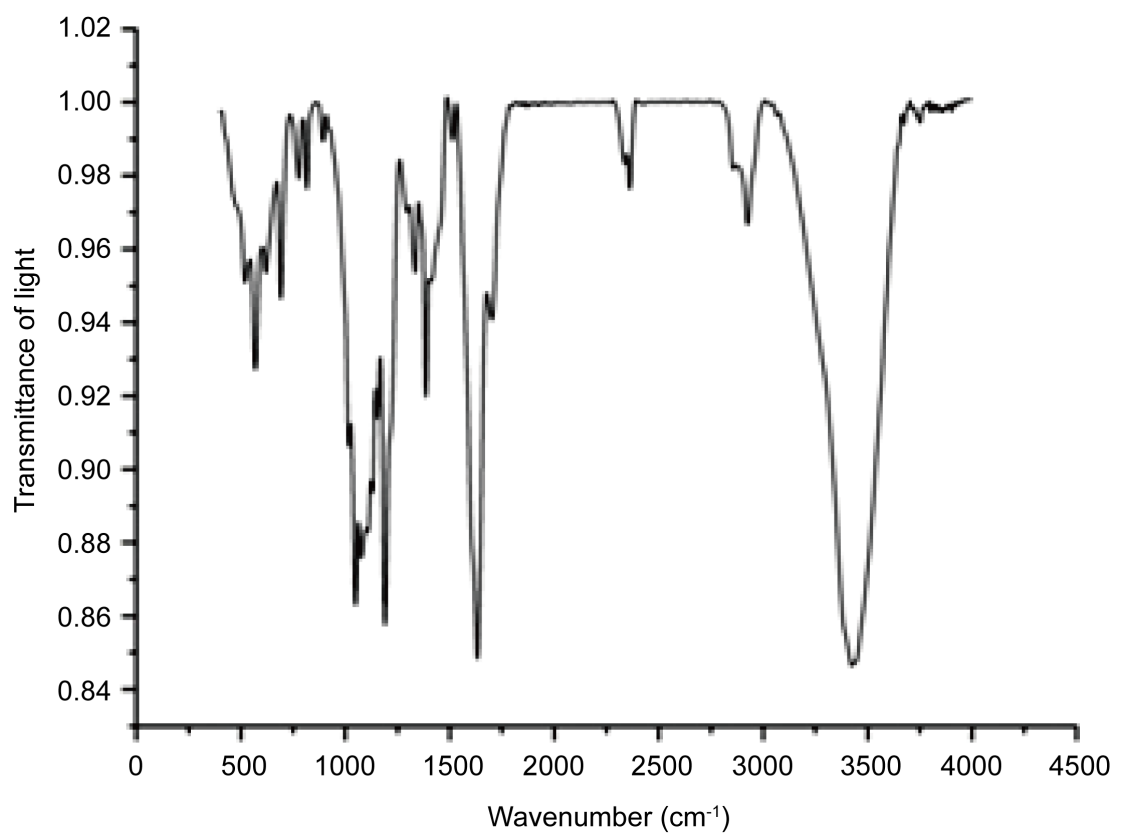

Figure 5. Fourier Transform Infrared Spectroscopy of green walnut shell dyes [Using FTIR spectrophotometer (Brukar vertex 100, Germany)]. 
aromatic groups (C-C). In case of wavelength $1580-1650 \mathrm{~cm}^{-1}$ medium bend of the figure in the above group indicates that $1^{\circ}$ amine group $(\mathrm{N}-\mathrm{N})$ is present there. Nitriles group $(C \equiv N)$ were indicated by the stretches in the wavelength $2210-2260 \mathrm{~cm}^{-1}$.

In the wavelength $2748-2890 \mathrm{~cm}^{-1}$ there is a medium stretch which indicates that there is an aldehyde group $(\mathrm{H}-\mathrm{C}=\mathrm{O}) 2748-2890 \mathrm{~cm}^{-1}$ wavelength also shows medium stretch which indicates the aldehyde group $(\mathrm{H}-\mathrm{C}=\mathrm{O})$ in the graph. Alkanes group $(\mathrm{C}-\mathrm{H})$ was identified by the medium stretch of the figure in the wavelength range $2850-3000 \mathrm{~cm}^{-1}$. In the wave length range $3200-3500$ $\mathrm{cm}^{-1}$ there is a strong broad stretch which indicates that there are alcohols and phenols group ( $\mathrm{O}-\mathrm{H}$ group) is present there. Thus, different functional groups of gardenia yellow dyes were investigated in different wavelengths with respect to standard characteristics of the infrared spectroscopy. According to the above test, we found that in case of green walnut shell dyes presence of aldehyde group, alkanes group, alkyl halide group are dominating group among the various functional groups.

\subsection{Colour Strength Test of S/J Cotton Knit Fabrics}

\subsubsection{SEM Images of the Pre-, Meta- and Post-Mordanting Effect}

In the Figure 6 and Figure 7 shows the difference between Pre and After modifying the pre-, meta- and post-mordanting effect. We can see clearly if we modify the mordanting the K/S value will be stable for mass production. In the following Table 1 shows the simple and after modifying mordanting effect with walnut dyeing on $\mathrm{S} / \mathrm{J}$ cotton knit fabric.

From the above result Table 1, it has been found that pre-mordanted cotton dyed sample dyeing with $1 \mathrm{~mL} \mathrm{FeSO}_{4}$ mordant gave the $\mathrm{k} / \mathrm{s}$ value 0.78 . On the other hand, meta- and post-mordanted cotton dyed sample dyeing with $1 \mathrm{~mL}$ $\mathrm{FeSO}_{4}$ mordant gave the $\mathrm{k} / \mathrm{s}$ value 0.56 and 0.76 . Moreover pre-mordanted cotton dyed sample dyeing with $1.5 \mathrm{~mL} \mathrm{FeSO}_{4}$ mordant gave the $\mathrm{k} / \mathrm{s}$ value 2.86. On the other hand, meta- and post-mordanted cotton dyed sample dyeing with 1.5

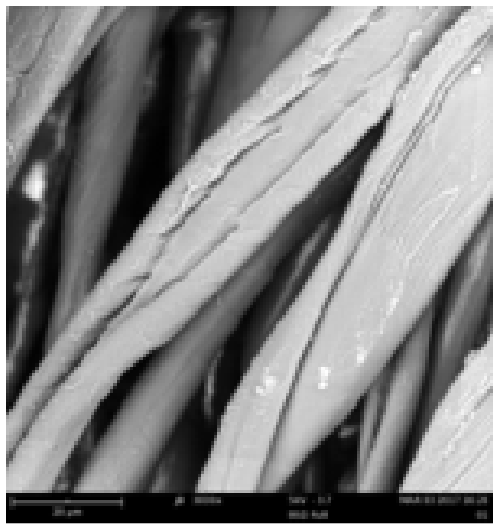

(a)

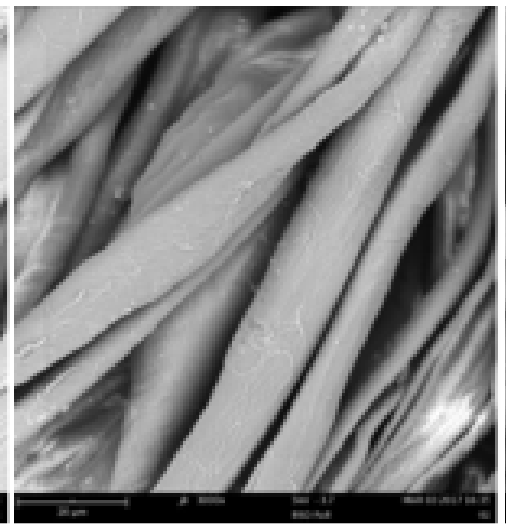

(b)

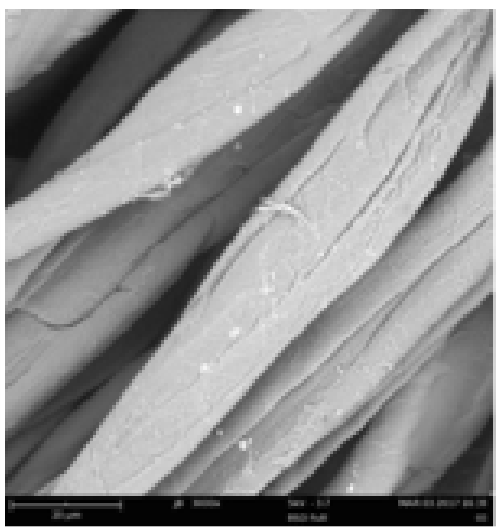

(c)

Figure 6. SEM image of the (a) Pre-, (b) Meta- and (c) Post-mordanting effect (Before modifying). 


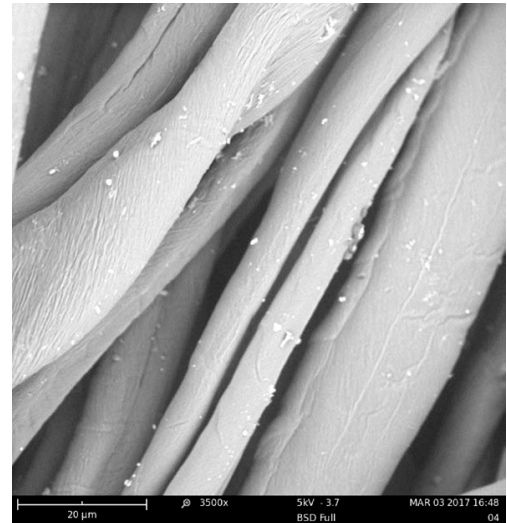

(a)

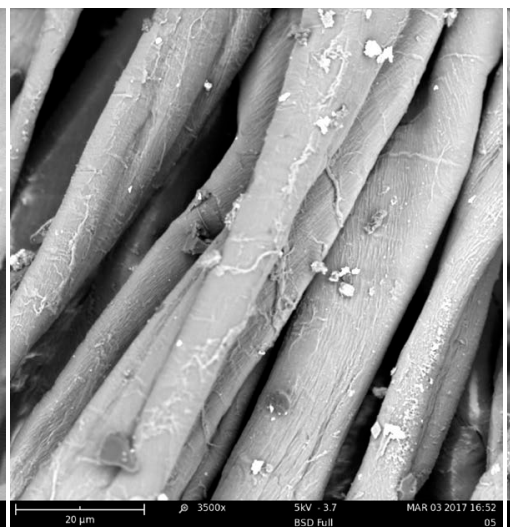

(b)

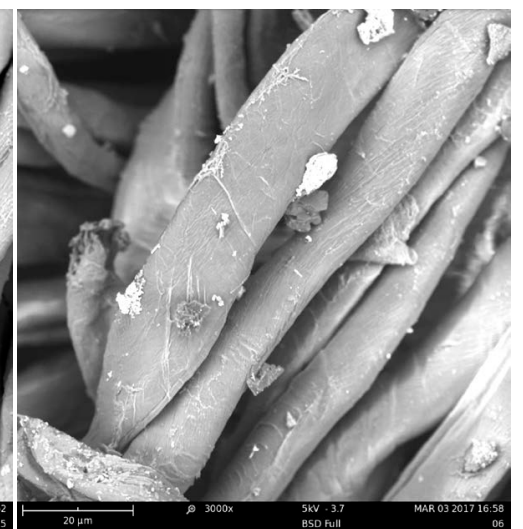

(c)

Figure 7. SEM image of the (a) Pre-, (b) Meta- and (c) Post-mordanting effect (After modifying).

Table 1. Colour Strength Test of cotton knitted fabrics dyed with Green walnut shell dye.

\begin{tabular}{|c|c|c|c|c|c|c|c|c|c|c|c|c|}
\hline \multirow{2}{*}{$\begin{array}{l}\text { Mordant } \\
\left(\mathrm{FeSO}_{4}\right)\end{array}$} & \multicolumn{4}{|c|}{ Pre-mordanting } & \multicolumn{4}{|c|}{ Meta-mordanting } & \multicolumn{4}{|c|}{ Post-mordanting } \\
\hline & $\mathrm{K} / \mathrm{S}$ & $\mathrm{L}^{*}$ & $a^{*}$ & $b^{*}$ & $\mathrm{~K} / \mathrm{S}$ & $\mathrm{L}^{*}$ & $a^{*}$ & $b^{*}$ & $\mathrm{~K} / \mathrm{S}$ & $\mathrm{L}^{*}$ & $a^{*}$ & $b^{*}$ \\
\hline $1.5 \mathrm{~mL}$ & 2.86 & -0.38 & -0.83 & -0.64 & 2.57 & -0.35 & -0.80 & -0.60 & 2.78 & -0.37 & -0.82 & -0.62 \\
\hline $2 \mathrm{~mL}$ & 4.68 & -0.69 & 0.04 & 3.65 & 3.67 & -0.66 & 0.02 & 3.60 & 3.80 & -0.68 & 0.03 & 3.62 \\
\hline $2.5 \mathrm{~mL}$ & 5.00 & 1.13 & -3.90 & -7.42 & 4.0 & 1.10 & -3.87 & -7.39 & 4.40 & 1.12 & -3.89 & -7.41 \\
\hline $3 \mathrm{~mL}$ & 4.23 & 2.41 & -3.88 & -9.82 & 3.25 & 2.39 & -3.82 & -9.80 & 3.56 & 2.40 & -3.85 & -9.81 \\
\hline $3.5 \mathrm{~mL}$ & 2.91 & 1.25 & -3.83 & -7.83 & 2.23 & 1.22 & -3.78 & -7.80 & 2.43 & 1.23 & -3.80 & -7.82 \\
\hline
\end{tabular}

*The colour difference is expressed by the following equation: $\mathrm{DE}^{\star}=\left(\mathrm{Da}^{*}\right)^{2} \times\left(\mathrm{Db}^{\star}\right)^{2}$.

$\mathrm{mL} \mathrm{FeSO}_{4}$ mordant gave the $\mathrm{k} / \mathrm{s}$ value 2.57 and 2.78. Furthermore increasing the mordant amount during dyeing pre-mordanted sample improves the colour strength value of sample when compared to meta- and post-mordanted sample. On the contrary passage of certain period of time by changing the amount of mordant it was obtained that when the amount of mordant was above 2.5 slight decrease of colour strength was visible for meta-, post-, pre-mordanting cotton sample. From the above discussion, we can see that when cotton knitted fabric sample dyed with $2.5 \mathrm{ml} \mathrm{FeSO}_{4}$ mordant during pre-mordanting method gave the best $\mathrm{k} / \mathrm{s}$ value compared to other mordanting method and the colour strength of that pre-mordanted dyed samples are more than meta- and post-mordanted dyed sample.

\subsubsection{Mordanting Effect on S/J Cotton Knit Fabric with Green Walnut Shell}

From Figure 8 we can see the effect of mordanting on the dyed Single jersey cotton knit fabric at 70 Degree, $\mathrm{pH} 4$ for $60 \mathrm{~min}, \mathrm{M}$ :L ratio will be 1:5.

\subsubsection{Rubbing Fastness Test of Cotton Knitted Fabrics [26]}

Among these values from Table 2, we have found that pre-mordanted cotton knitted fabric dyed with $2.5 \mathrm{ml} \mathrm{FeSO}_{4}$ mordant in dyeing machine gave the best 
Table 2. Dry rubbing test of cotton knitted fabrics dyed with green walnut shell dye.

\begin{tabular}{ccccccc}
\hline & \multicolumn{5}{c}{ Mordant $\left(\mathrm{FeSO}_{4}\right)$} \\
\hline Method & $1 \mathrm{ml}$ & $1.5 \mathrm{ml}$ & $2 \mathrm{ml}$ & $2.5 \mathrm{ml}$ & $3 \mathrm{ml}$ & $3.5 \mathrm{ml}$ \\
\hline Pre mordanting & 4 & $4-5$ & 4 & 5 & $4-5$ & 4 \\
Meta mordanting & $4-5$ & 4 & 4 & $4-5$ & $3-4$ & 4 \\
Post mordanting & $4-5$ & $4-5$ & 4 & $4-5$ & 4 & 4 \\
\hline
\end{tabular}

${ }^{*}$ The above readings were taken in grey scale in the range of $5 *$ ISO 105-D02standard rubbing fastness test method is used [26].

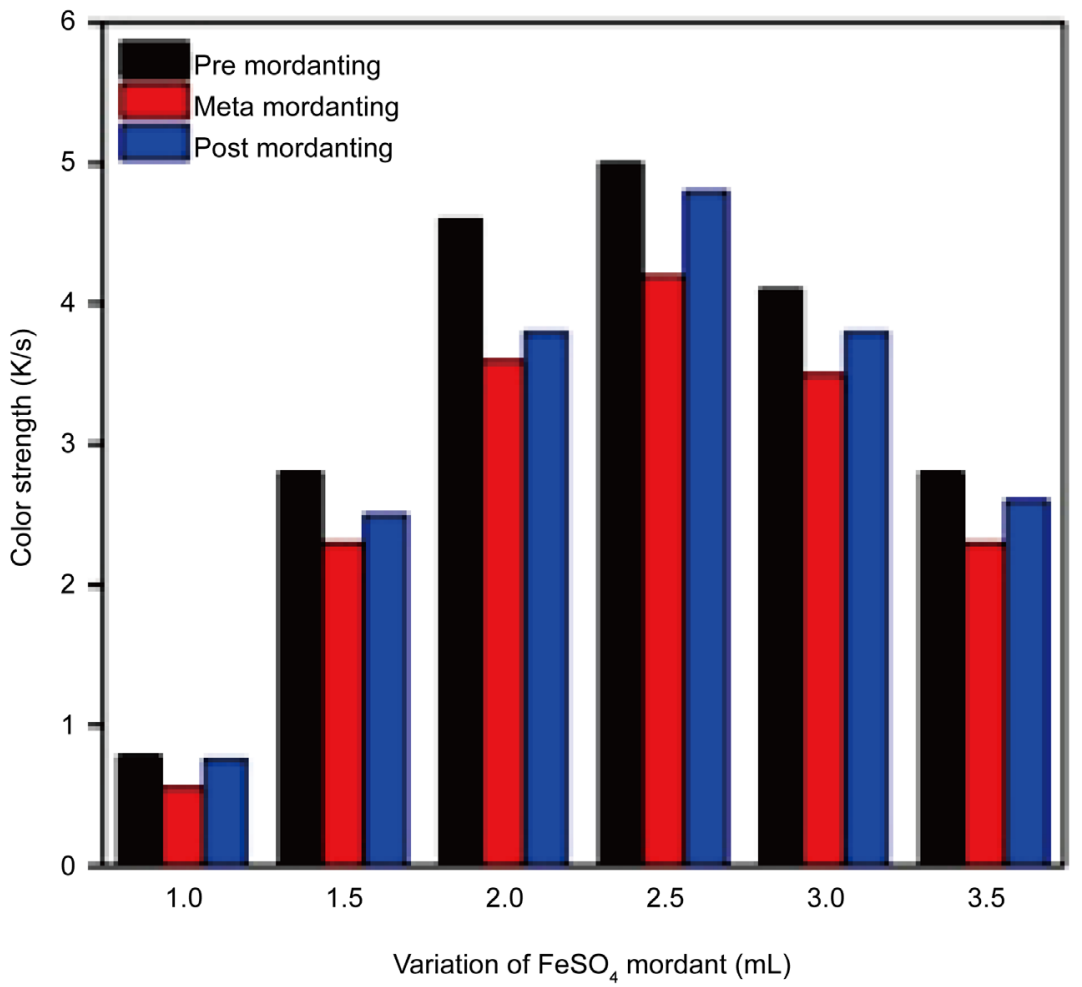

Figure 8. Effect of mordanting on the dyed S/J cotton knit fabric at $70^{\circ} \mathrm{C}, \mathrm{pH} 4$ for $60 \mathrm{~min}$, $\mathrm{M}: \mathrm{L}=1: 15$.

result (5 in grey scale) as compared with meta- and post-mordanting cotton dyed sample which are shown in above table. Chirat $M$ revealed that dyeing of cotton yarn with leaves of Eupatorium odoratum L by using aqueous extraction influenced on the properties of dyeing and other factor that was related to save the environment from the bad weather.

Among these values from Table 3, we have found that pre-mordanted cotton knitted fabric dyed with $2.5 \mathrm{ml} \mathrm{FeSO}{ }_{4}$ mordant in dyeing machine gave the best result (5 in grey scale) as compared with meta- and post-mordanting cotton dyed sample which are shown in above table. Several researchers investigating the utility of natural dyes and mordants have tested dye exhaustion, colour nice, and colour fastness homes with varied effects, relying on the complicated interplay amongst fiber kind, mordant agent, dye type, and alertness parameters (e.g., substrate coaching, thing awareness, time, temperature, and so forth). The mor- 
Table 3. Wet rubbing test of S/J cotton knit fabric with green walnut shell dye.

\begin{tabular}{ccccccc}
\hline & \multicolumn{5}{c}{ Mordant $\left(\mathrm{FeSO}_{4}\right)$} \\
\hline Method & $1 \mathrm{ml}$ & $1.5 \mathrm{ml}$ & $2 \mathrm{ml}$ & $2.5 \mathrm{ml}$ & $3 \mathrm{ml}$ & $3.5 \mathrm{ml}$ \\
\hline Pre-mordanting & 4 & $4-5$ & 4 & 5 & $4-5$ & 4 \\
Meta-mordanting & $4-5$ & 4 & 4 & $4-5$ & $3-4$ & 4 \\
Post-mordanting & $4-5$ & $4-5$ & 4 & $4-5$ & 4 & 4 \\
\hline
\end{tabular}

*The above readings were taken in grey scale in the range of 5 .

dant type can have an impact on dye-fiber association and as a consequence colour fastness to moist and mechanical treatments (e.g., crocking) as well as light fastness.

\subsubsection{Washing Fastness Test of S/J Cotton Knit Fabrics}

Here from Table 4 we can compare to $1 \mathrm{ml}$ ferrous sulphate mordant when pre-, meta-, post-mordanted S/J cotton knit fabric was done by using the slight variation of $3 \mathrm{ml} \mathrm{FeSO}_{4}$ fastness rating was lower that was 3, 3 and $2-3$ through the assessment of grey scale. In addition to $3.5 \mathrm{ml} \mathrm{FeSO}{ }_{4}$ mordant gave comparatively higher wash fastness rating as compared to $3 \mathrm{ml} \mathrm{FeSO}_{4}$ mordanted solution which was 3-4, 4 - 5 and 4 - 5 for pre-, meta-, post-mordanting method.

Furthermore we can see from Table 5 as compared to $1 \mathrm{ml}$ ferrous sulphate mordant when pre-, meta-, post-mordanted S/J cotton knit fabric was done by using the slight variation of $3 \mathrm{ml} \mathrm{FeSO}_{4}$ fastness rating was lower that was 4 through the assessment of grey scale. In addition to $3.5 \mathrm{ml}$ ferrous sulphate mordant gave comparatively higher wash fastness rating as compared to $3 \mathrm{ml}$ ferrous sulphate mordanted solution which was 5 for pre-, meta-, post-mordanting method.

The following samples are the indicator of before wash and after wash treatment. From the following picture we can the difference between before and after wash. From the picture it is clear that after dyeing with walnut shell the washing percentage is good. Here, in Figure 9 and Figure 10 shows the sample from pre, post and meta-mordanting section serially.

\subsubsection{Light Fastness Test of S/J Cotton Knit Fabrics}

Among these values from Table 6, we have found that pre-, meta-, post-mordanted S/J cotton knit fabric dyed with extracted dyes solution using $2.5 \mathrm{ml}$ ferrous sulphate mordant in dyeing machine gave the best result (3 - 4 in grey scale). In case of solution pre-, meta-, post-mordanted S/J cotton knit fabric dyed with extracted dyes solution using $1.5 \mathrm{ml}$ ferrous sulphate mordant in dyeing machine gave the result ( 2 in grey scale) which are shown in above table. Moreover pre-, meta-, post-mordanted S/J cotton knit fabric dyed with extracted dyes solution using $1 \mathrm{ml}$ ferrous sulphate mordant in dyeing machine gave the fastness rating of 2 - 3 through the assessment of grey scale. Furthermore as compared to $1 \mathrm{ml}$ ferrous sulphate mordant when pre-, meta-, post-mordanted 
Table 4. Wash fastness to colour staining.

\begin{tabular}{ccccccc}
\hline \multirow{2}{*}{ Method } & \multicolumn{5}{c}{ Mordant $\left(\mathrm{FeSO}_{4}\right)$} \\
\cline { 2 - 7 } & $1 \mathrm{ml}$ & $1.5 \mathrm{ml}$ & $2 \mathrm{ml}$ & $2.5 \mathrm{ml}$ & $3 \mathrm{ml}$ & $3.5 \mathrm{ml}$ \\
\hline Pre-mordanting & $3-4$ & $4-5$ & 3 & $4-5$ & 3 & $3-4$ \\
Meta-mordanting & 3 & $4-5$ & 3 & $4-5$ & 3 & $4-5$ \\
Post-mordanting & $3-4$ & $4-5$ & 3 & $4-5$ & $2-3$ & $4-5$ \\
\hline
\end{tabular}

*ISO-105-C06 standard washing fastness test method is used [26].

Table 5. Wash fastness to colour change.

\begin{tabular}{ccccccc}
\hline \multirow{2}{*}{ Method } & \multicolumn{5}{c}{ Mordant $\left(\mathrm{FeSO}_{4}\right)$} \\
\cline { 2 - 6 } & $1 \mathrm{ml}$ & $1.5 \mathrm{ml}$ & $2 \mathrm{ml}$ & $2.5 \mathrm{ml}$ & $3 \mathrm{ml}$ & $3.5 \mathrm{ml}$ \\
\hline Pre-mordanting & 4 & $4-5$ & 4 & 5 & 4 & 5 \\
Meta-mordanting & 4 & $4-5$ & 4 & 5 & 4 & 5 \\
Post-mordanting & 4 & $4-5$ & 4 & 5 & 4 & 5 \\
\hline
\end{tabular}

Table 6. Light fastness test of S/J cotton knit fabrics dyed with green walnut shell dye.

\begin{tabular}{ccccccc}
\hline \multirow{2}{*}{ Mordant } & \multicolumn{5}{c}{ Mordant $\left(\mathrm{FeSO}_{4}\right)$} \\
\cline { 2 - 6 } & $1 \mathrm{ml}$ & $1.5 \mathrm{ml}$ & $2 \mathrm{ml}$ & $2.5 \mathrm{ml}$ & $3 \mathrm{ml}$ & $3.5 \mathrm{ml}$ \\
\hline Pre-mordanting & $2-3$ & 2 & $2-3$ & $3-4$ & $2-3$ & $2-3$ \\
Meta-mordanting & $2-3$ & 2 & 3 & $3-4$ & $2-3$ & $2-3$ \\
Post-mordanting & $2-3$ & 2 & $2-3$ & $3-4$ & 3 & 3 \\
\hline
\end{tabular}

${ }^{*}$ Conducted by A Q-SUN Xenon test chamber Model Xe-1 ${ }^{*}$ ISO 105-B02 standard light fastness test method [26].
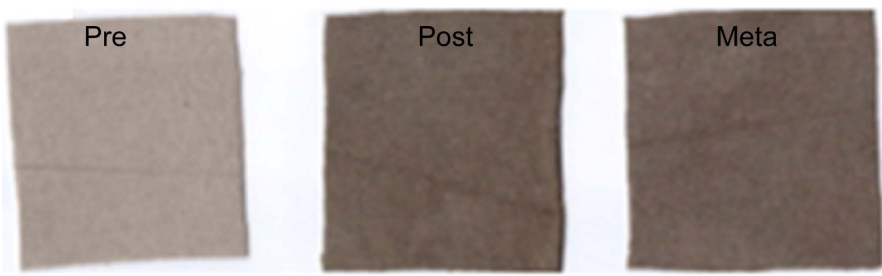

Figure 9. Before washing appearance.
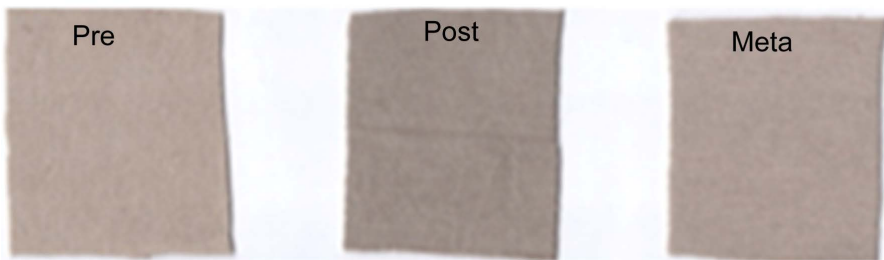

Figure 10. After washing appearance.

S/J cotton knit fabric was done by using the slight variation of $3 \mathrm{ml} \mathrm{FeSO}$ fastness rating was little bit similar that was $2-3,2-3$ and 3 through the assessment of grey scale. In addition to other variation of ferrous sulphate mordant gave similar wash fastness rating when $3.5 \mathrm{ml}$ ferrous sulphate mordanted solution 
was used which was 2 - 3, 2 - 3 and 3 for pre-, meta-, post-mordanting method.

\subsubsection{Ultraviolet Protection Factor (UPF) Analysis of S/J Cotton Knit Fabric}

The Ultraviolet protectionfactor of S/J cotton knit fabric dyed with green walnut shell dye on the S/J cotton knit fabric was analyzed by using AATCC 183 standard testing methodand results obtained were represented in Table 7 . The results indicate that the green walnut shell dye exhibited good UPF properties on the dyed substrate when dyed in the presence of ferrous sulfate mordant. Pre-mordanted S/J cotton knit fabric give higher protection factor when compared with meta- and post-mordanted fabric. Ultra violet protection factor of pre-mordanted fabric is 2000, 1776 and 1988 whereas ultra violet protection factor of meta-mordanted fabric is 344,388 and 438 and ultra violet protection factor of post-mordanted fabric is 953, 912 and 749. Moreover Ultra violet sun ray A percentage of pre-mordanted fabric is $1.27,1.03$ and 1.14 whereas ultra violet sun ray A percentage of meta-mordanted fabric is $0.87,0.94$ and 0.98 and ultra violet sun ray A percentage of post-mordanted fabric is $0.63,0.60$ and 0.57 . Furthermore Ultra violet sun ray B percentage of pre-mordanted fabric is 0.07 , 0.06 whereas ultra violet sun ray B percentage of meta-mordanted fabric is 0.06 and ultra violet sun ray B percentage of post-mordanted fabric is 0.60 . The effect of mordanting on UPF shows that by giving more time for dyeing more dyes will enter into the amorphous regions of the fiber and hence we can get darker shades. The darker shades will impart more protection from ultraviolet light. The UVA and UVB resistance shows the same trend as UPF. The UV blocking properties of extracts could be attributed to the presence of flavonoids and phenolic contents in it. Both these groups of compounds have been found to shield the plant tissues from damaging UV radiation during their growth. This is because of strong absorbance of UV radiations (particularly UVB radiations) by these compounds.

From the following sample we get the effect of UV\%, UPF. Here, the Figure 11 shows the sample from pre-, post- and meta-mordanting section serially.

Table 7. The effect of mordant on UPF, UVA\% blockage UVB\% blockage.

\begin{tabular}{ccccc}
\hline Mordanting method & Number of test & UPF & UVA\% & UVB\% \\
\hline \multirow{3}{*}{ Pre-mordanting } & 1 & 2000 & 1.27 & 0.07 \\
& 2 & 1776 & 1.03 & 0.06 \\
& 3 & 1988 & 1.14 & 0.06 \\
Meta-moradnting & 1 & 344 & 0.87 & 0.06 \\
& 2 & 388 & 0.98 & 0.06 \\
Post-mordanting & 3 & 438 & 0.63 & 0.06 \\
& 1 & 953 & 0.60 & 0.06 \\
\end{tabular}



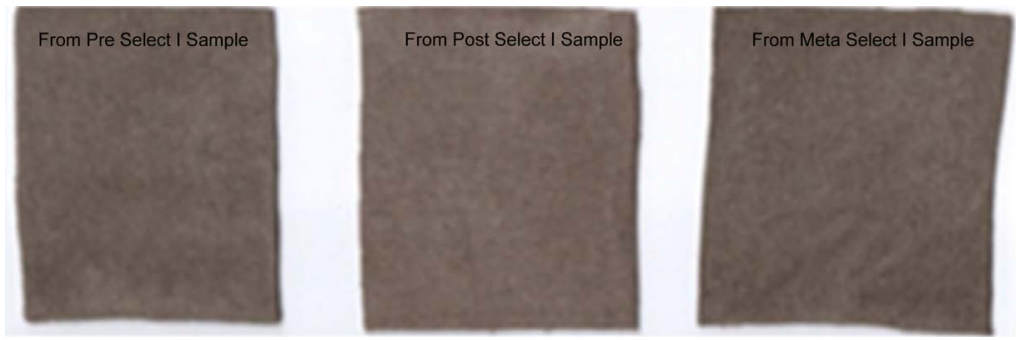

Figure 11. The sample for UV\%, UPF test.

\section{Conclusion}

Green walnut shell dyes were extracted by using aqueous extraction methods that is ancient method. During the aqueous extraction process, at first dried pieces of green walnut shell were kept at $28^{\circ} \mathrm{C}$ temperature for 24 hours then it was used for dye extraction. The plant materials and distilled water ratio were 1:30 and boiled at $100^{\circ} \mathrm{C}$ temperature with $1 \mathrm{~g} / \mathrm{L} \mathrm{NaOH}$ for one and a half hours. The method of ancient technology improves the dyeing performance of S/J cotton knit fabric. It was found that green walnut shell dyes in powder form extracted from water by traditional method was good. The test results like Fourier Transform Infrared Spectroscopy (FTIR) of the extracted powder form was good. After extraction of green walnut shell dye before dyeing process, ferrous sulphate mordants were applied in different amounts in different conical flax with the dyes solution to find out the best dyeing results. Here $1 \mathrm{ml}, 1.5 \mathrm{ml}, 2 \mathrm{ml}$, $2.5 \mathrm{ml}, 3 \mathrm{ml}, 3.5$ mordants were used together with pure gardenia yellow dyes solution in different conical flax. Aqueous extracted dyes solution was used for dyeing of S/J cotton knit fabric with ferrous sulphate mordant which was used with the dye solution in different amounts to increase the affinity of the dyeing. After dyeing, different tests of the dyed sample was done like colour strength test $(\mathrm{k} / \mathrm{s})$, colour fastness to wash, colour fastness to rubbing, colour fastness to light etc. to check the fastness properties of S/J cotton knit dyed sample. According to the test results of the different dyed sample, rubbing fastness of the all pre-mordanted dyed sample was good and washing fastness of the pre-mordanted dyed samples was satisfactory as compared to meta-, post-mordanted sample. Aqueous extracted dyes solution with $2.5 \mathrm{ml}$ ferrous sulphate mordents gives the best result. Light fastness results of the dyed sample were not so good. Colour yield value for aqueous extracted dyes solution used in dyeing for $\mathrm{S} / \mathrm{J}$ cotton knit fabric was evaluated by $(\mathrm{k} / \mathrm{s})$ value that was good for pre-mordanted fabric. Finally, Green walnut shell dyes extraction by using aqueous extraction machine is comparatively good in comparing with different test results rather than the other extraction methods. Its fastness property was good; process is simple, high colour yield than other extraction methods and can be used for the further commercial use.

\section{References}

[1] Saxena, S. and Raja, A. (2014) Natural Dyes: Sources, Chemistry, Application and 
Sustainability Issues. In: Muthu, S., Eds., Roadmap to Sustainable Textiles and Clothing. Textile Science and Clothing Technology, Springer, Singapore, 37-80. https://doi.org/10.1007/978-981-287-065-0_2

[2] Ghaheh, F.S., et al. (2014) Assessment of Antibacterial Activity of Wool Fabrics Dyed with Natural Dyes. Journal of Cleaner Production, 72, 139-145. https://doi.org/10.1016/j.jclepro.2014.02.050

[3] Mirjalili, M. and Karimi, L. (2013) Extraction and Characterization of Natural Dye from Green Walnut Shells and Its Use in Dyeing Polyamide: Focus on Antibacterial Properties. Journal of Chemistry, 2013, Article ID: 375352. https://doi.org/10.1155/2013/375352

[4] Teh, W.X., et al. (2015) Pretreatment of Macadamia Nut Shells with Ionic Liquids Facilitates both Mechanical Cracking and Enzymatic Hydrolysis. ACS Sustainable Chemistry \& Engineering, 3, 992-999.

https://doi.org/10.1021/acssuschemeng.5b00126

[5] Miah, M.R., Telegin, F.Y. and Rahman, M.S. (2016) Eco-Friendly Dyeing of Wool Fabric Using Natural Dye Extracted from Onion's Outer Shell by Using Water and Organic Solvents. International Research Journal of Engineering and Technology, 3, 450-467.

[6] Vankar, P.S. and Shanker, R. (2009) Eco-Friendly Pretreatment of Silk Fabric for Dyeing with Delonix regia Extract. Coloration Technology, 125, 155-160. https://doi.org/10.1111/j.1478-4408.2009.00189.x

[7] Samanta, A.K. and Konar, A. (2011) Dyeing of Textiles with Natural Dyes. In: Akcakoca Kumbasar, E., Ed., Natural Dyes, InTech, Fontana.

[8] Ali Khan, M., Shahid-Ul-Islam and Mohammad, F. (2016) Extraction of Natural Dye from Walnut Bark and Its Dyeing Properties on Wool Yarn. Journal of Natural Fibers, 13, 458-469. https://doi.org/10.1080/15440478.2015.1055033

[9] Jihad, R. (2014) Dyeing of Silk Using Natural Dyes Extracted from Local Plants. Head of the Textile Engineering Department at Kombolcha, Institute of Technology, Wollo University, Ethiopia.

[10] Ferreira, B.S., de Campos, C.I. and Gonçalves, M.T.T. (2014) Use of Macadamia Nutshell in the Production of Eucalyptus Salign Particleboards. Advanced Materials Research, 1025-1026, 246-250.

https://doi.org/10.4028/www.scientific.net/AMR.1025-1026.246

[11] Mohammad, F. (2014) Emerging Green Technologies and Environment Friendly Products for Sustainable Textiles. In: Roadmap to Sustainable Textiles and Clothing, Springer, Berlin, 63-82.

[12] Miah, M.R., et al. (2017) Comparative Analysis of Colour Strength and Fastness Properties on Extracts Natural Dye from Onion's Outer Shell and Its Use in Eco-Friendly Dyeing of Silk Fabric. International Journal of Photochemistry and Photobiology, 2, 1-8.

[13] Ghaheh, F.S., et al. (2012) The Effect of Mordant Salts on Antibacterial Activity of Wool Fabric Dyed with Pomegranate and Walnut Shell Extracts. Coloration Technology, 128, 473-478. https://doi.org/10.1111/j.1478-4408.2012.00402.x

[14] Soleymani, S., Ireland, T. and McNevin, D. (2016) Effects of Plant Dyes, Watercolors and Acrylic Paints on the Colorfastness of Japanese Tissue Papers. Journal of the American Institute for Conservation, 55, 56-70. https://doi.org/10.1080/01971360.2015.1103101

[15] Fengel, D. and Wegener, G. (1984) Wood: Chemistry, Ultrastructure, Reactions. 
Walter de Gruyter, 613, 1960-1982.

[16] Lehto, J. and Alén, R. (2013) Alkaline Pre-Treatment of Hardwood Chips Prior to Delignification. Journal of Wood Chemistry and Technology, 33, 77-91. https://doi.org/10.1080/02773813.2012.748077

[17] Vvu, S. and Argyropoulos, D. (2003) An Improved Method for Lsolating Lignin in High Yield and Purity. Journal of Pulp and Paper Science, 29, 235-240.

[18] Dilling, P. and Sarjeant, P.T. (1984) Reduction of Lignin Color. Patent US4454066.

[19] Prabhu, K. and Bhute, A.S. (2012) Plant Based Natural Dyes and Mordants: A Review. Journal of Natural Product and Plant Resources, 2, 649-664.

[20] Bukhari, M.N., et al. (2017) Effect of Binary and Ternary Combination of Metal Salt Mordants on Dyeing and Fastness Properties of Natural Protein Fibre with Juglans regia L. Dye. Journal of Natural Fibers, 14, 519-529.

[21] Goodell, B., et al. (1997) Low Molecular Weight Chelators and Phenolic Compounds Isolated from Wood Decay Fungi and Their Role in the Fungal Biodegradation of Wood. Journal of Biotechnology, 53, 133-162.

https://doi.org/10.1016/S0168-1656(97)01681-7

[22] Asaduzzaman, M.M., Hossain, F. and Li, X. (2016) A Study on the Effects of Pre-Treatment in Dyeing Properties of Cotton Fabric and Impact on the Environment. Journal of Textile Science \& Engineering, 6, 2.

[23] Mishra, A. (2007) Natural Dyes from Pseudomonas fluorescens. Extraction, Characterization and Optimization of Dyeing Process for Textiles. GB Pant University of Agriculture and Technology, Pantnagar-263145 (Uttarakhand).

[24] Bukhari, M.N., et al. (2017) Dyeing Studies and Fastness Properties of Brown Naphtoquinone Colorant Extracted from Juglans regia L. on Natural Protein Fiber Using Different Metal Salt Mordants. Textiles and Clothing Sustainability, 3, 3. https://doi.org/10.1186/s40689-016-0025-2

[25] Doty, K., Haar, S. and Kim, J. (2016) Black Walnut, Osage Orange and Eastern Redcedar Sawmill Waste as Natural Dyes: Effect of Aluminum Mordant on Color Parameters. Fashion and Textiles, 3, 22. https://doi.org/10.1186/s40691-016-0074-9

[26] Samanta, A.K. and Agarwal, P. (2009) Application of Natural Dyes on Textiles. IJFTR, 34, 384-399. 